\title{
In-situ BIODIESEL SYNTHESIS FROM MICROALGAE Nannochloropsis Oculata USING NiO NANOCATALYST
}

\author{
P. Purkan ${ }^{1,}{ }^{凶}$, A. Safa ${ }^{1}$, A. Abdulloh ${ }^{1}$, A. Baktir ${ }^{1}$, R. Arissirajudin ${ }^{1}$, \\ H. Hermansyah ${ }^{3}$ and S.W. Kim ${ }^{1,2}$ \\ ${ }^{1}$ Department of Chemistry, Faculty of Science and Technology, Airlangga University. Jl. \\ Mulyorejo, Surabaya 60115, Indonesia. \\ ${ }^{2}$ Department of Chemical and Biological Engineering, Korea University, Korea \\ ${ }^{3}$ Department of Chemistry, Faculty of Mathematic and Natural Sciences, Sriwijaya University, \\ Palembang, South Sumatera, Indonesia 30662 \\ ${ }^{\square}$ Corresponding Author: purkan@fst.unair.ac.id
}

\begin{abstract}
Biodiesel is an alternative fuel or biofuel that can be produced from microalgal oil. Nannochloropsis oculata is a species of marine microalgae that is easily cultivated and has a high content of lipid. $N$. oculata lipids can be extracted efficiently using $\mathrm{NiO}$ nanocatalyst as cell disruption agent and organic solvents. The optimal treatment time for $\mathrm{NiO}$ nanocatalyst is 96 hours in chloroform. At the optimized conditions, the lipid extract from N. oculata reached 34.20 $\pm 0.52 \%$ of the total weight. The conversion of microalgal oil into biodiesel is carried out with a transesterification reaction using three different catalysts, respectively. Biodiesel conversion with $\mathrm{NiO}$ nanocatalyst is better than that with the other catalysts of $\mathrm{NaOH}$ and $\mathrm{HCl}$. The conversion yield of microalgal oil to biodiesel with $\mathrm{NiO}$ nanocatalyst reaches $89.72 \%$. Based on the advantage of $\mathrm{NiO}$ nanocatalyst as both a cell disruption agent and a catalyst, biodiesel production can be performed in an in-situ way. The conversion yield of biodiesel was $85.54 \%$ within 60 mins.
\end{abstract}

Keywords: Biodiesel, Biofuel, Microalgae, N. oculata, NiO Nanocatalyst.

RASĀYAN J. Chem., Vol. 14, No.3, 2021

\section{INTRODUCTION}

Fossil fuels are non-renewable, so they will be a problem for availability for future generations. The exploitation of fossil fuels has been carried out continuously, even predicted that there will be an increase until the year 2025. ${ }^{1}$ In addition, the burning process of fossil fuels can produce adverse effects on the environment and human health because it releases air pollutants like carbon dioxide $\left(\mathrm{CO}_{2}\right)$, nitrogen oxides (NOx), sulfur dioxide $\left(\mathrm{SO}_{2}\right)$, carbon monoxide $(\mathrm{CO})$, and other reactive hydrocarbons. For this reason, efforts need to be made to obtain renewable and environmentally friendly energy sources, likely biodiesel as an alternative fuel. Biodiesel represents a fuel containing a mixture of mono-alkyl esters from long-chain fatty acids or also known as methyl ester fatty acids (FAME). It has lower toxicity because has no emissions of aromatic compounds. One of the raw materials that have been developed is microalgal oil from various microalgae. ${ }^{2,3,15}$

Nannochloropsis oculata is one of the species of marine unicellular microalgae found in Indonesian waters. $N$. oculata has been reported to have a high content of lipid. ${ }^{4}$ Factors that affect biodiesel production from the microalgae are the lipid extraction stage and the method of converting oil into biodiesel (transesterification) that requires some catalysts like $\mathrm{HCl}, \mathrm{NaOH}$, and metal oxide or enzyme. ${ }^{2,3,14,15}$ To get the maximum yield of lipid the right method is needed. One study reported that cell wall disruption and lipid harvesting in Chlorella vulgaris simultaneously using nano nickel oxide (nano NiO) showed satisfactory results. ${ }^{5}$

Interestingly, besides having the ability to damage cell walls, nucleophilic properties of nano $\mathrm{NiO}$ can also act as a good heterogeneous catalyst in transesterification reactions. ${ }^{6,8}$ Nanocatalyst also has a high resistance to saponification reactions and has good rigid properties ${ }^{7}$ based on the advantages possessed by nano $\mathrm{NiO}$, it would apply to in situ biodiesel production from $N$. oculata. In situ biodiesel production from

Rasayan J. Chem., 14(3), 2097-2103(2021)

http://doi.org/10.31788/RJC.2021.1436317

This work is licensed under a CC BY 4.0 license. 
$N$. oculata which represents simultaneous extraction and transesterification processes is reported in the paper.

\section{EXPERIMENTAL}

\section{Synthesis and Characterization of Nickel Oxide Nanocrystals (Nano NiO)}

$\mathrm{NiO}$ nanocrystal is synthesized by the sol-gel method. The $\mathrm{NiCl}_{2} \cdot 6 \mathrm{H}_{2} \mathrm{O}$ precursor as $5,257 \mathrm{~g}$ dissolved in $20 \mathrm{~mL}$ of methanol, then stirred for $60 \mathrm{~min}$ at room temperature. The $5.0 \mathrm{M} \mathrm{NaOH}$ is added drop by drop into the mixed solution, followed by a strong stirrer for $\pm 120 \mathrm{~min}$ at room temperature until a bright green gel is formed. The gel was dried at $100-110^{\circ} \mathrm{C}$ for $1 \mathrm{~h}$, then treated in the furnace at $450^{\circ} \mathrm{C}$ for $1 \mathrm{~h} .{ }^{8}$ The final product that shows a black $\mathrm{NiO}$ nanocrystalline powder was characterized by X-ray diffraction $(\mathrm{XRD}){ }^{9}$

\section{Lipid Extraction}

The dry sample of $3 \mathrm{~g} \mathrm{~N}$. oculata in $50 \mathrm{~mL}$ water was mixed with $2.5 \mathrm{~g}$ of nano $\mathrm{NiO}$, then incubated at 24 , 48, 72, 96 and $120 \mathrm{~h}$ by tightly stirring. The mixture was centrifuged for $5 \mathrm{~min}$ at $7000 \mathrm{rpm}$, then the supernatant was removed. The chloroform as $5 \mathrm{~mL}$ was added to the sample, then treated by a vortex for 1 $\mathrm{h}$ at room temperature. The filtrate was evaporated to remove the solvents, whereas the extract of lipid is dried in an oven at $100{ }^{\circ} \mathrm{C}$ for $1.5 \mathrm{~h}$, then it was weighed. The sample was treated without nano NiO used as a control.

\section{Microalgal Lipid Conversion to Biodiesel}

The $50 \mathrm{~mL}$ oil sample isolated from $N$. oculata was reacted with $10 \mathrm{~mL}$ methanol in various catalysts such as $\mathrm{HCl}, \mathrm{NaOH}$ and $\mathrm{NiO}$. The reaction was run at $65^{\circ} \mathrm{C}$ in reflux at $65^{\circ} \mathrm{C}$ for $60 \mathrm{~min}$. In turn, the mixture was cooled at room temperature, then transferred to a separating funnel. The perfect reaction was shown by the occurrence of 2 layers, then the biodiesel that resided in the top layer separated. The biodiesel yielded was analyzed by GC-MS.

\section{In Situ Biodiesel Synthesis.}

As much as $50 \mathrm{~g}$ of the dry weight of $N$. oculata was reacted simultaneously with $5 \mathrm{~g}$ NiO nanocatalyst and $25 \mathrm{~mL}$ of methanol. The reaction firstly runs in the reflux at room temperature for $96 \mathrm{~h}$, then followed to a temperature of $65^{\circ} \mathrm{C}$ for $2 \mathrm{~h}$. The next process was the same with lipid conversion work to biodiesel.

\section{Analysis of Biodiesel}

Analysis and determination of the FAME percentage were carried out with GC-MS. The FAME yield is calculated with the following formulations:

$$
\% \text { Conversion }=\frac{C_{i s} \times A_{f} \times I R F}{A_{i s}}
$$

The IRF, Ais, AF, Cis and Cf constitute to Internal response factor, the area from internal standard, area of FAME on the sample, the concentration of internal standard, and concentration of FAME from internal standard internal.

\section{Synthesis of Nickel Oxide Nanocrystal (Nano NiO)}

\section{RESULTS AND DISCUSSION}

Nickel (II) chloride hexahydrate $(\mathrm{NiCl} 2.6 \mathrm{H} 2 \mathrm{O})$ was used as a nano $\mathrm{NiO}$ synthesis precursor by the sol-gel method. Methanol and $5 \mathrm{M} \mathrm{NaOH}$ were used for a solvent and deposition agent respectively. The reaction is as follows:

$$
2 \mathrm{NaOH}+\mathrm{NiCl}_{2} \cdot 6 \mathrm{H}_{2} \mathrm{O} \rightarrow 2 \mathrm{NaCl}+\mathrm{Ni}(\mathrm{OH})_{2} \downarrow+6 \mathrm{H}_{2} \mathrm{O}
$$

The formed gel is light green (Fig- 1A) then calcinated at $450^{\circ} \mathrm{C}$ in the furnace for $60 \mathrm{~min}$, so that $\mathrm{NiO}$ nanocrystals were formed, based on the following reaction:

$$
\mathrm{Ni}(\mathrm{OH})_{2} \rightarrow \mathrm{NiO}+\mathrm{H}_{2} \mathrm{O}
$$

The final product obtained was black $\mathrm{NiO}$ nanocrystals (Fig-1). The x-ray diffraction techniques are used to determine the crystallinity of $\mathrm{NiO}$ nanocrystal. 
RASĀYAN J. Chem.

Vol. 14 | No. 3 |2097-2103| July - September | 2021

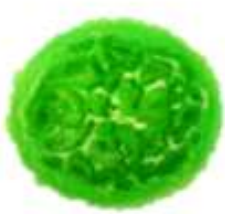

A

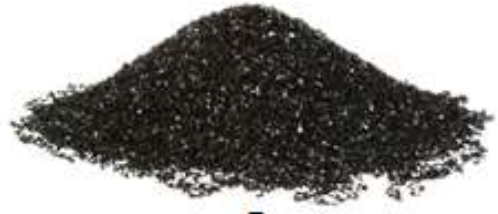

B

Fig.-1: The Product of Nanocrystal NiO Synthesis. The NiO Gel (A) and NiO Nanocrystal (B).

The analysis of the synthesized $\mathrm{NiO}$ nanocrystal with XRD showed a diffractogram in Fig-2. The data was managed by Match2 program, then it represented the reference pattern of NiO 96-101-0094 and NiO 96101-0382 (Fig- 2). The signal peaks of crystalline nano NiO are at an angle (20) 37.22; 43.23; 62.72; 75.24; 79.22; and 94.92. The report showed that the $\mathrm{NiO}$ nanocrystal has been synthesized.

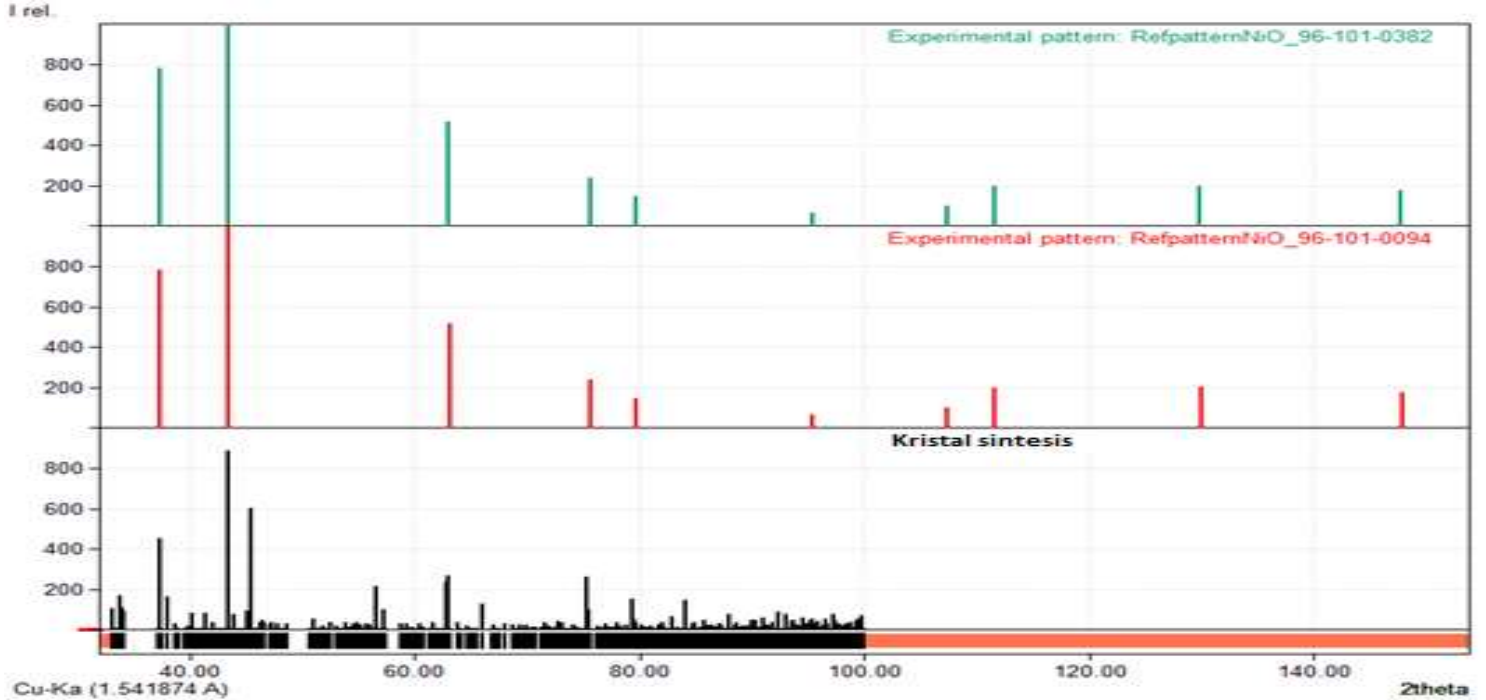

Fig.-2: Diffractogram of the NiO Synthetic Crystal

The size of the nanocrystals was determined with the Williamson-Hull Plot formula ${ }^{9}$ based on the XRD data in Fig-2. The plot resulted a linear regression $y=0.1766 x-0.0059$, where $y=\beta \cos (\theta)$ and $x=\sin (\theta)$. From the intersection of the lines on the $y$ axis and the gradient, the size of the synthesized nickel oxide can be calculated, namely $\mathrm{D}=5.12 \mathrm{~nm}$ (Fig-3).

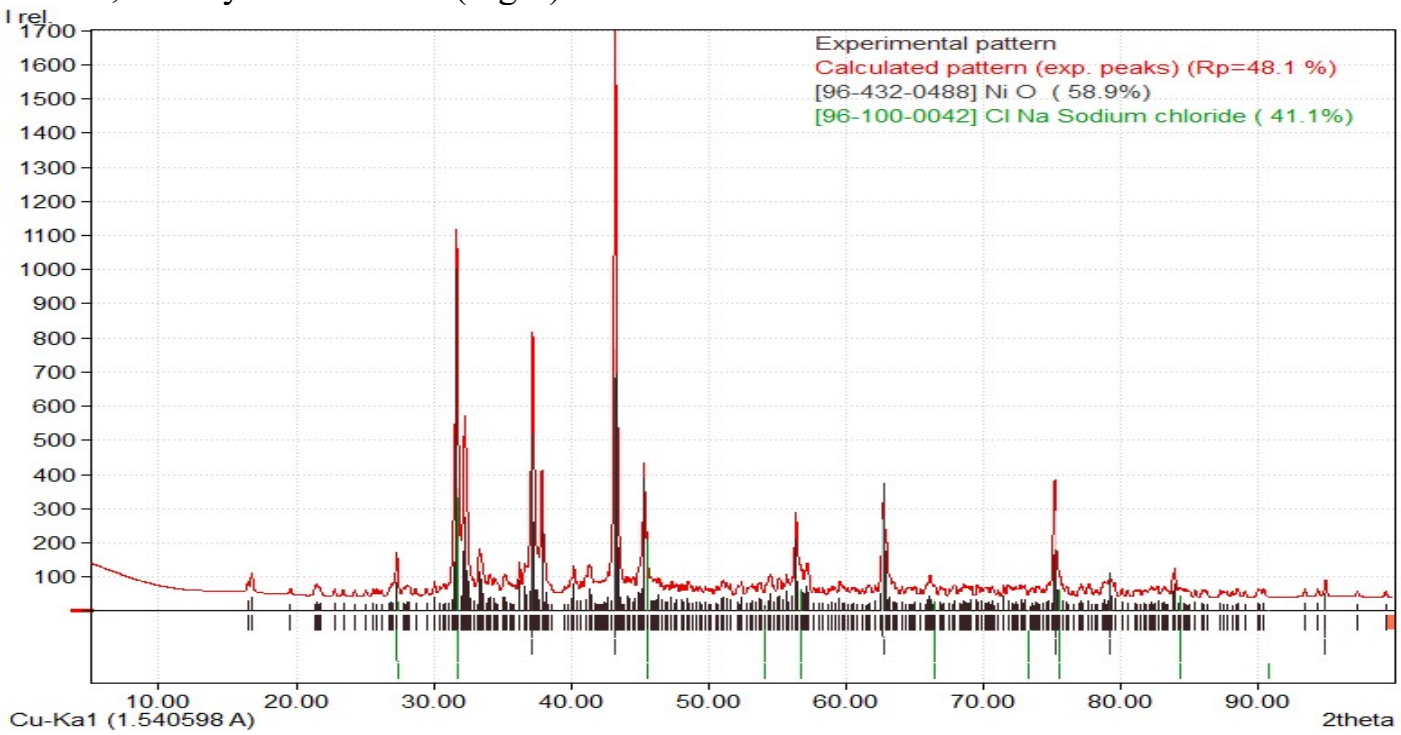

Fig.- 3: The Similarity of the Diffractogram of synthesized NiO Nanocrystal. 


\section{Lipid Extraction with NiO Nanocrystal}

Lipids will be very easily extracted using organic solvents after the cell wall system is damaged. Microalgal cells are protected by a rigid thick sheath consisting of carbohydrates and glycoproteins and also have chemical resistance. ${ }^{10,11.15}$ The cell wall of $N$. oculata has fibrillar and amorphous components. The most common fibrillar component is cellulose, a polymer of 1,4 related D-glucose, whereas amorphous component is proteins, lipids, and polysaccharides. ${ }^{10}$ The nanoparticle of nickel oxide contributes to damage microalgal membrane which facilitates the release of lipids. It can cause a loss of cell membrane integrity (disruption). ${ }^{10,13}$ The mechanism underlying the disruption and extraction of microalgal lipids by nano $\mathrm{NiO}$ in an aqueous solution has been suggested. The surface of $\mathrm{NiO}$ nanoparticles undergoes protonation/deprotonation through the following reaction. ${ }^{8,11}$

$$
\mathrm{H}_{2} \mathrm{O}+\mathrm{Ni}-\stackrel{-\mathrm{O}}{\underset{\mathrm{OH}_{-}^{+}}{\stackrel{+}{\rightleftharpoons}}} \mathrm{Ni}-\mathrm{OH} \underset{\mathrm{OH}_{-}^{+}}{\stackrel{+}{\rightleftharpoons}} \mathrm{Ni}-\mathrm{OH}_{2}
$$

The presence of functional groups such as carboxyl (-COOH), hydroxyl (-OH), phosphate (-PO3); amino $(-\mathrm{NH} 2)$; and sulfhidryl (-SH) of integral protein in the surface of the microalgal cell wall gave a negative effect on the disruption and extraction in aqueous solution. ${ }^{11,12}$ Therefore, after the addition of nano NiO to microalgal cells, nano $\mathrm{NiO}$ electrostatically interacts with microalgae and forms cell-particle complexes and eventually experiences physical disturbances in the cell wall, so that lipids can be harvested without long stages and can reduce production costs. ${ }^{5}$ The mechanical disturbance and lipid extraction of $N$. oculata cells would be described by the mechanism in Fig-4.

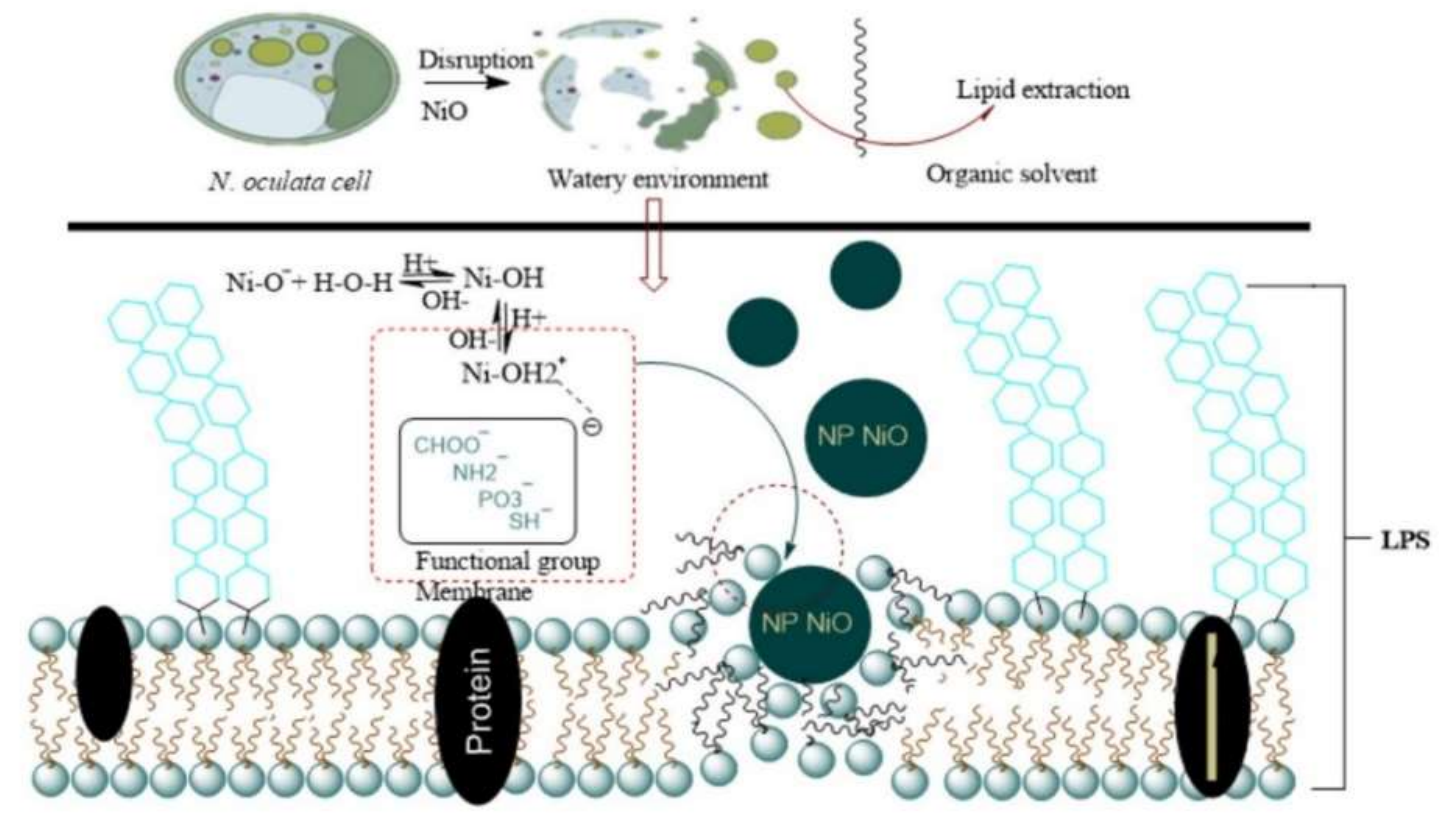

Fig.- 4: The Mechanism of N. oculata Cell Wall Noise Reaction with Nano NiO disrupting Agent

The lipid extract obtained by nano $\mathrm{NiO}$ treatment for $24 \mathrm{~h}$ was $5.31 \pm 1.51 \%$, while in the control (without nano $\mathrm{NiO}$ treatment) the extracted lipid was only $0.91 \pm 0.52 \%$. Furthermore, in this study, the extraction process by nano $\mathrm{NiO}$ treatment was also carried out concerning time. The variation of reaction time taken was 24, 48, 72, 96 and $120 \mathrm{~h}$. The longer the nano $\mathrm{NiO}$ treatment was carried out, the more lipid was extracted. The increase of lipid continued until the reaction time was $96 \mathrm{~h}$, reaching $34.20 \pm 0.52 \%(\mathrm{w} / \mathrm{w})$ (Fig-5). When the reaction time was $120 \mathrm{~h}$, the lipid extract was slightly increased. However, this increase was not significant. So the optimal reaction time for this extraction method was $96 \mathrm{~h}$. 


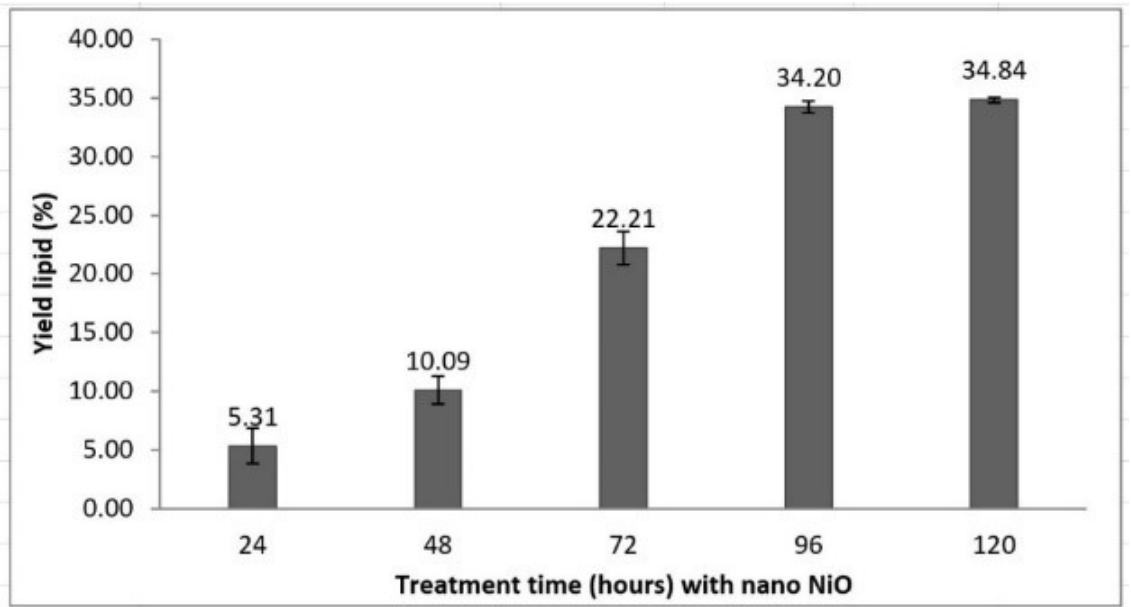

Fig.-5: The Lipid Yield was extracted from $N$. oculata with Nano NiO various times.

\section{Biodiesel Synthesis}

The synthesis was done in two ways, ie lipid conversion and in situ method which use $N$. oculata cell directly. The conversion of $N$. oculata lipid to methyl ester fatty acids (FAME) was performed by three catalysts $\mathrm{HCl}, \mathrm{NaOH}$, and $\mathrm{NiO}$ nano. Analysis of the biodiesel or FAME product with GC-MS resulted in a mass spectrum of chromatograms that describes a fragmentation for methyl ester fatty acids from the sample (Fig.-6).

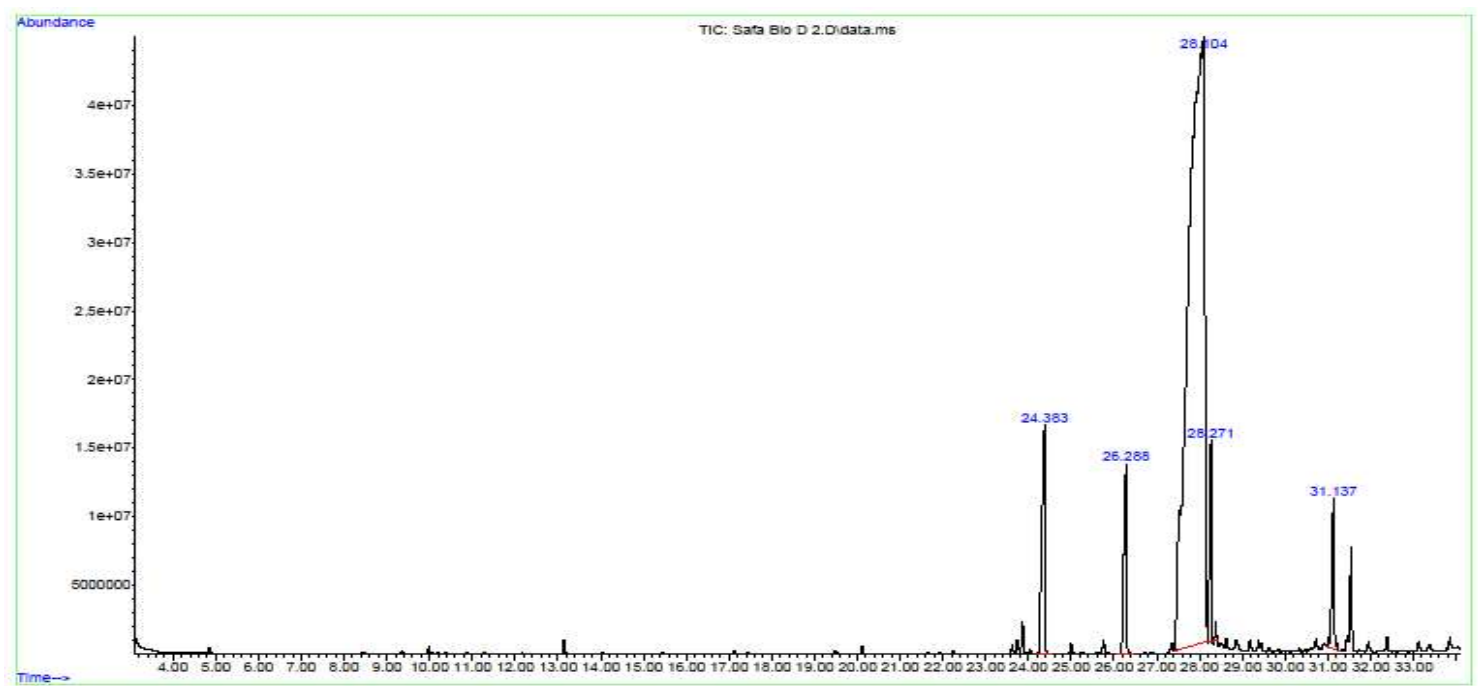

Fig.- 6: Synthesis of Biodiesel Chromatogram using NiO Nanocatalyst

From the results of data processing of GC-MS, it is known that biodiesel synthesis using nano NiO catalyst showed better conversion than that using acid catalyst $(\mathrm{HCl})$ and alkaline catalyst $(\mathrm{NaOH})$. The FAME yielded with an acid catalyst $(\mathrm{HCl})$ was $28.61 \%$, whereas with an alkaline catalyst $(\mathrm{NaOH})$ was $83.09 \%$. The highest yield was obtained by $\mathrm{NiO}$ nanocatalyst as $89.72 \%$ (Fig-7). Nanocatalyst could be a promising alternative for the efficient production of biodiesel. These properties of nano $\mathrm{NiO}$ are very beneficial to be separated again, so it will reduce the production cost.

The second way on the biodiesel is through in situ conversion of N. oculata directly to biodiesel. The way presented a simultaneous step between extraction and transesterification reaction. By using the in-situ method with $\mathrm{NiO}$ nanocatalyst, the process yielded a total of FAME as $85.54 \%$ for $96 \mathrm{~h}$ process. The product is a little lower than yielded by the conventional method (Fig.-8). Considering the results of both conventional and in situ biodiesel production, it can be concluded that the use of $\mathrm{NiO}$ nanocatalyst could 


\section{RASĀYAN J. Chem.}

Vol. 14 | No. 3 |2097-2103| July - September | 2021

improve the biodiesel conversion process. Especially, in situ method has several advantages such as the conversion is high, the operation is relatively easy and simple, it does not require a long production stage, use of fewer materials and tools, and less energy consumption. Therefore, with some optimization in subsequent research, in situ biodiesel production from $N$. oculata would be very interesting to study.

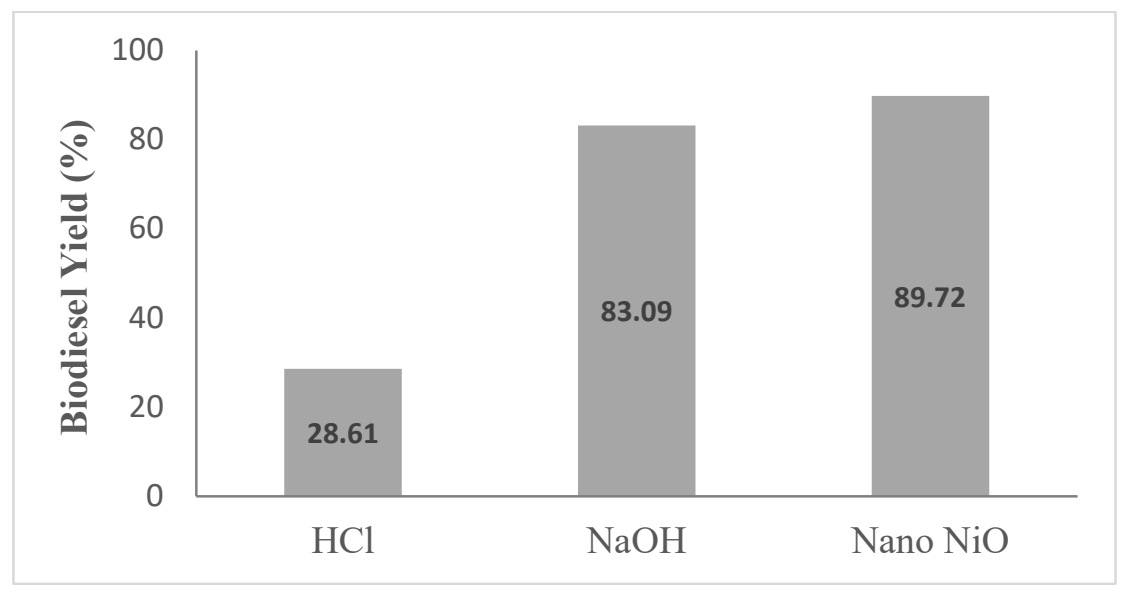

Fig.-7: Biodiesel Yield from Oil Transesterification with Various Catalysts. The highest yield is prepared by using a catalyst of Nano NiO.

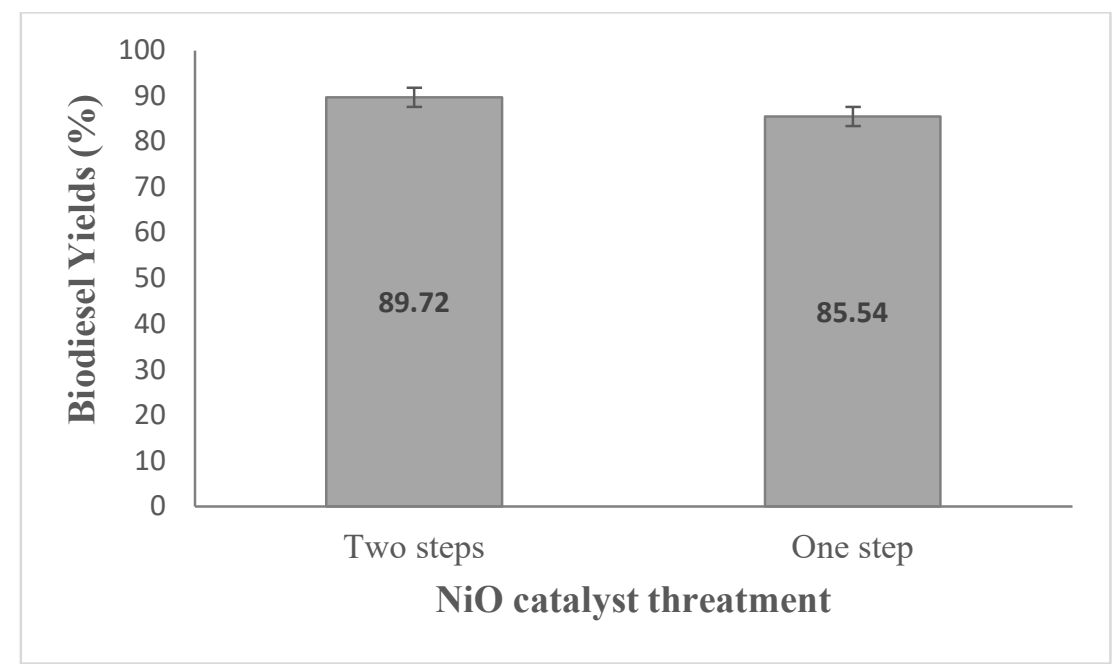

Fig.-8: Biodiesel Yield resulted from the Addition of Nano NiO via conventional and In situ methods. The yields are seen as almost similar

\section{CONCLUSION}

$N$. oculata was cultured with the mixotrophic method on 7-Modified media (BG-11 plus NaNO3 and glucose), showing the specific growth rate $(\mu)$ of $2.6 \mathrm{~g} \mathrm{~L}^{-1}$ and the doubling time $\left(\mathrm{t}_{\mathrm{d}}\right)$ of $6.40 \mathrm{~h}$. Lipid extraction from $N$. oculata by nano $\mathrm{NiO}$ treatment can be improved, compared to control. The optimum reaction time is $96 \mathrm{~h}$ when the yield was obtained as much as $34.20 \pm 0.52 \%(\mathrm{~b} / \mathrm{b})$. The fatty acids from $N$. oculata lipids consist of oleic acid, stearic acid, palmitic acid, and eicocene acid (EPA). With the acid catalyst $(\mathrm{HCl})$, the conversion of $N$. oculata oil to FAME was $28.61 \%$, whereas the alkaline catalyst $(\mathrm{NaOH})$ showed $83.09 \%$. Nano $\mathrm{NiO}$ is a more efficient catalyst than $\mathrm{HCl}$ and $\mathrm{NaOH}$ catalysts, considering the biodiesel conversion of $89.72 \%$. In situ biodiesel production is a simultaneous extraction and transesterification process. The conversion of in situ biodiesel production using $\mathrm{NiO}$ nanocatalyst was $85.54 \%$ at $96 \mathrm{~h}$ when using microalgae $N$. oculata as a substrate. 
RASĀYAN J. Chem.

Vol. 14 | No. 3 |2097-2103| July - September | 2021

\section{ACKNOWLEDGEMENT}

KEMENRISTEK RI supported the research through a letter no: 27/E1/KPT/2020 and contract no: 4/AMD/E1/KP.PTNBH/2020 and 829/UN3.14/PT/2020

\section{REFERENCES}

1. V. Jorge, Gallo, and L.R, Waldyr, Energy, 104, 237(2016), https://doi.org/10.1016/j.energy.2016.03.130

2. P. Purkan, E. Nidianti, A. Abdulloh, A. Safa, W. Retnowati, W. Soemarjati, H. Nurlaila and S.W. Kim, Open Chemistry, 17(1), 919(2019), https://doi.org/10.1515/chem-2019-0102

3. P. Purkan, I.T. Lestari, R. Arissirajudin, R.R.P. Ningsih, W. Apriyani, H. Nurlaila, S. Sumarsih, S. Hadi, W. Retnowati and S.W. Kim, Rasayan Journal of Chemistry, 13(4), 2074(2020), https://doi.org/10.31788/RJC.2020.1345697

4. S. Ohse, R.B. Derner, R.A. Ozório, and R.G. Corrêa, Idesia (Chile), 33(1), 93(2015), https://doi.org/10.4067/S0718-34292015000100010

5. W. Huang, and J. Kim, Nickel oxide nanoparticle-based method for simultaneous harvesting and disruption of microalgal cells, Bioresource Technology, 218, 1290(2016). https://doi.org/10.1016/j.biortech.2016.07.091

6. A.K. Sharma, S. Desnavi, C. Dixit, U. Varshney, and A. Sharma, Chemical Engineering and Applications, 6(3), 156(2015), https://doi.org/10.7763/ijcea.2015.v6.472

7. S. Hu, Y. Guan, Y. Wang, and H. Han, Applied Energy, 88(8), 2685(2011), https://doi.org/10.1016/j.apenergy.2011.02.012

8. K. Sherly, N. Warda, and K. Miftahul, Makara Journal of Science, 21(1), 19(2017), https://doi.org/10.7454/mss.v21i1.7533

9. M. Sumadiyasa, and I.B.S. Manuaba, Buletin Fisika, 19(1), 28(2018), https://doi.org/10.24843/bf.2018.v19.i01.p06

10. W. Jiang, K. Yang, R.W Vachet, B. Xing, Langmuir, 26(23), 18071(2010), https://doi.org/10.1021/la103738e

11. N.N. Nassar, Journal of Hazardous Materials, 184(1-3), 538(2010), https://doi.org/10.1016/j.jhazmat.2010.08.069

12. C.M. Monteiro, P.M. Castro, and F.X. Malcata, Biotechnology Progress, 28, 299(2012), https://doi.org/10.1002/btpr.1504

13. L. Xu, C. Guo, F. Wang, S. Zheng, and C. Z. Liu, Bioresource Technology, 102(21), 10047(2011), https://doi.org/10.1016/j.biortech.2011.08.021

14. P. Purkan, E. Huruniawati and S. Sumarsih, Journal of Chemical Technology and Metallurgy, 52(6), 1079(2017).

15. A.L. Ahmad, N.H. Mat Yasin, C.J.C, Derek, and J.K. Lim, Renewable and Sustainable Energy Reviews, 15(1), 584(2011), https://doi.org/10.1016/j.rser.2010.09.018

[RJC-6317/2020] 